\title{
Takotsubo cardiomyopathy associated with sepsis due to Pseudomonas aeruginosa pneumonia
}

\section{Cardiomiopatia de Takotsubo associada à sepse decorrente de pneumonia por Pseudomonas aeruginosa}

Márcio da Silva Pereira ${ }^{1}$, Gabriel Dantas Sarubbi ${ }^{1}$, Renan Barbosa Rodrigues ${ }^{1}$, Maria Rafaelle Lourenço Fontenele ${ }^{1}$, Daniele Rocha Queiroz Lemos ${ }^{2,3,4}$

1. Estudante de Medicina do Centro Universitário Christus (Unichristus), Ceará, Brasil. 2. Doutoranda em Saúde Coletiva pela Universidade Estadual do Ceará (UECE), Ceará, Brasil. 3. Núcleo de Vigilância Epidemiológica da Secretaria da Saúde do Estado do Ceará (SESA-CE), Ceará, Brasil. 4. Docente da Faculdade de Medicina do Centro Universitário Christus (Unichristus), Ceará, Brasil.

\begin{abstract}
The authors describe a case report of a 71 year-old female patient admitted at the emergency service due to severe precordial chest pain associated with dyspnea and sweating. The electrocardiogram performed on admission showed ST elevation on V2 and V3 leads and the ventriculography revealed left ventricular apical ballooning, denoting the diagnosis of Takotsubo Cardiomyopathy. At the eighth day of hospitalization, although the heart function was recovered, the patient died due the clinical complications of a septic shock.
\end{abstract}

Keywords: Takotsubo Cardiomyopathy. Sepsis. Ventricular Dysfunction. Myocardial Stunning.

\section{Resumo}

Os autores reportam o caso de uma paciente de 71 anos de idade, do sexo feminino, admitida no pronto-socorro com um quadro de dor precordial, de forte intensidade, associada à dispneia e sudorese. A eletrocardiografia realizada na admissão revelou supradesnivelamento do segmento ST em parede anterior (V2 e V3) e a ventriculografia demonstrou balonamento apical da parede ventricular esquerda, denotando o diagnóstico de Cardiomiopatia de Takotsubo. No 8o dia de internação, apesar da recuperação da função cardíaca, a paciente veio a óbito devido à evolução para choque séptico.

Palavras-chave: Cardiomiopatia de Takotsubo. Sepse. Disfunção Ventricular. Miocárdio Atordoado.

\section{INTRODUCTION}

The Takotsubo Cardiomyopathy (TCM), also known as the Broken Heart Syndrome, constitutes a nosological entity and a rare cause of transient left ventricular dysfunction, in the absence of significant coronary artery disease. It is characterized by a precordial chest pain associated with electrocardiographic changes and a mild release of cardiac enzymes, mimicking acute myocardial infarction ${ }^{1}$. This disease occurs, typically, as a result of the presence of physical or emotional stress, such as the death of a loved one, involvement in accidents, exacerbation of chronic diseases, surgery, abuse of illegal drugs with adrenergic activity and sepsis ${ }^{2,3,4}$. The prognosis is usually favorable to the full recovery of all changes that characterize the TCM within two to four weeks ${ }^{1,2}$.

The association among sepsis and TCM has already been reported. It is believed that in the sepsis thereoccurs an excessive increase of catecholamines in the sympathetic nerve endings which stimulate the heart, precipitating the onset of some events, such as: transient left ventricular apical ballooning, multivessel epicardial spasm or diffuse coronary microvascular dysfunction ${ }^{5,6}$. In this report, the case of a patient with TCM associated with sepsis of pulmonary etiology is described.

\section{CASE REPORT}

A 71 years old woman was admitted in an emergency service due to severe precordial chest pain that had started 6 (six) hours before the event, associated with dyspnea, pallor and sweating. Her past medical history included hypertension and smoking, but she had stopped smoking 11 years earlier. On examination, her body temperature was $37^{\circ} \mathrm{C}$, her blood pressure was $122 \times 93 \mathrm{mmHg}$, heart rate was $121 \mathrm{bpm}$ and respiratory rate was 15 breaths/min. On chest auscultation, breath sounds were abnormal with fine crackles in both lung bases. Electrocardiogram showed sinus tachycardia, ST elevation on V2 and V3 leads and T wave inversion in precordial leads V1 and V4 (fig.1). Coronary angiography presented coronary arteries without obstructions or significant lesions. Ventriculography showed left ventricular (LV) apical ballooning (fig.2). The transthoracic echocardiogram showed akinesis of the apical and mid ventricular segments, hyperkinesis of the left ventricular parabasal segments, and the left ventricular ejection fraction (LVEF) of $35 \%$. Left ventricular end diastolic diameter was $53 \mathrm{~mm}$, the left atrial diameter was $35 \mathrm{~mm}$, the right ventricle diameter was $25 \mathrm{~mm}$. On the following day, the patient developed respiratory failure with sepsis clinical features, requiring invasive mechanical ventilation.Blood cell 
count showed leukocytosis $\left(14.300 / \mathrm{mm}^{3}\right)$ and low hemoglobin (8,7 mg/dL). Platets serum concentration was normal (151.800/ $\mathrm{mm}^{3}$. Troponin I level was 0,309 $\mathrm{ng} / \mathrm{mL}$, CK-MB level was 6,43 $\mathrm{ng} / \mathrm{mL}$, glucose was $164 \mathrm{mg} / \mathrm{dL}$ and lactate was $1,9 \mathrm{mg} / \mathrm{dL}$. The metabolic panel was $\mathrm{Na}^{+}: 144 \mathrm{mmol} / \mathrm{L} ; \mathrm{K}+: 3,18 \mathrm{mmol} / \mathrm{L} ; \mathrm{Cl}-$ $: 104,7 \mathrm{mmol} / \mathrm{L}$.Arterial blood gas showed a respiratory acidosis ( $\mathrm{pH}=7,351 ; \mathrm{pCO} 2: 45.1 \mathrm{mmHg} ; \mathrm{HCO} 3-23.6 \mathrm{mmol} / \mathrm{L})$. The urinary and blood cultures revealed infection by Pseudomonas aeruginosa. The patient presented supraventricular tachycardia which was treated with amiodarone. Noradrenaline was initiated due to hypotension and imipenem and vancomycin because of the increase of leucocytosis. On the fourth day of hospital admission, an echocardiography was performed that revealed full recovery of the left ventricular function with global and segmental left ventricular contractility preserved in repose, without evidence of myocardial necrosis, denoting the diagnosis of CMT.Despite the cardiac function recovery, on the eighth day of hospitalization, there was the worsening of the clinical condition, progressing to septic shock leading to death due to multiple organ dysfunction.

Figure 1. Elevation of the ST segment in the anteroseptal leads (V2 and V3).

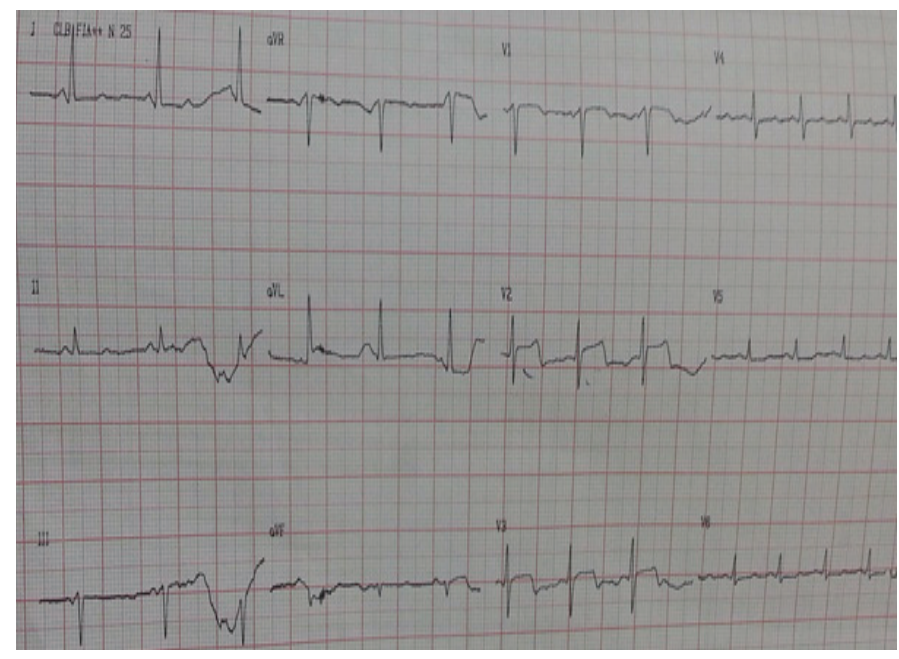

Figure 2. Apical ballooning of the left ventricle.

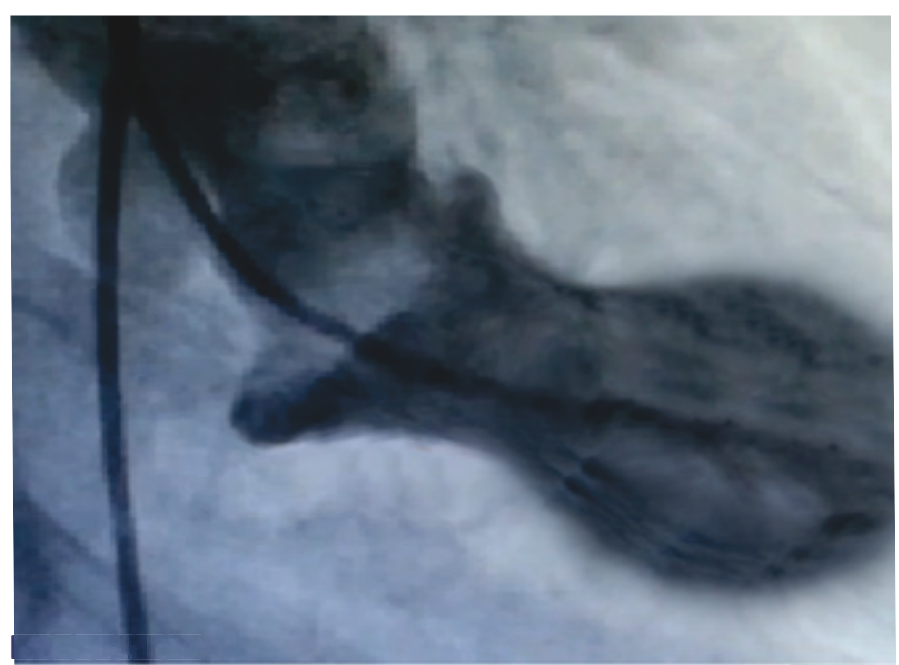

The first case of TCM was reported in Japan by Sato et al. in $1990^{7}$. Thereafter, many cases have already been described in Western countries, amidst a variety of ethnic groups. The name takotsubo is derived from a traditional Japanese fishingpot used for trapping octopus. The cardiac morphology during the systole on ventriculography of a patient with TCM resembles this Japanesepot ${ }^{8}$.

The exact prevalence of the TCM has not been well established yet, but it can be estimated that $1,97 \%$ of people who have been diagnosed with Acute Coronary Syndrome, actually, had TCM9.Eighty-eight percent of the cases happen in women with a mean age ranging from 58 to 77 years old. Only 2,7\% of the female are younger than 50 years old ${ }^{10}$.

The etiology of this disease is not well defined. The postulate mechanisms include increase in the catecholamine serum levels and coronary vasospasm. In most cases, there is a correlation with an event which may have caused physical or mental stress, such as: death of a loved one, surgery, invasive procedures or chronic disease exacerbation ${ }^{8}$.

Several guidelines have emerged to make takotsubo cardiomyopathy widely recognized, as well as to better define the diagnostics criteria. According to the most recent, as proposed by the Mayo Clinic (USA) and by Takotsubo Cardiomyopathy Study Group (Japan), Takotsubo cardiomyopathy can be defined by the following features: (1) Transient hypokinesis, akinesis or dyskinesis of the left ventricular mid segments with or without apical involvement. The regional wall presents motion abnormalities typically extended beyond a single epicardial coronary distribution. A stressful trigger is often, but not always present; (2) absence of obstructive coronary disease or angiographic evidence of acute plaque rupture; (3) new electrocardiographic abnormalities (either ST-segment elevation and/or T-wave inversion) or modest elevation in cardiac troponin; (4) absence of pheochromocytoma or myocarditis $^{11,12}$.

Reports of TCM associated with sepsis are rare. Suzuki et al. reported one case in the setting of Klebsiella pneumoniae sepsis in a diabetic patient ${ }^{13}$. Our patient had reversible segmental myocardial involvement with systolic dysfunction suggesting TCM in the setting of Pseudomonas sepsis. Most of the species of Pseudomonas have toxic extracellular proteins denominated toxin A (main virulence factor) and exoenzyme $S$; these proteins exert an essential role in pathogenesis of this kind of infection ${ }^{14}$. A previous study showed that toxin A increased the vulnerability of rat myocardium to hypoxic injuries and potentiated myocardial depression ${ }^{15}$. The Pseudomonas exotoxin A prevents beta-adrenoceptor-induced upregulation of Gi protein alpha-subunits and adenylyl cyclase desensitization in rat heart muscle cells ${ }^{15}$. Thus, this protein may lead to an increased catecholamine cardiotoxicity.

We speculate that the high serum levels of cytokines, catecholamines, Pseudomonas exotoxin A, and probably other 
substances from this bacteria developed the severe myocardial depression in our patient. Although the relation among sepsis and TMC is still to be investigated, there are few case reports which describe this association, what might suggest sepsis as a cause of TCM is poorly known.

Although most of the previous studies suggested an association of CMT with a stressor,in our case there was not a stressor clearly identified as the trigger of the syndrome. In literature, some studies have suggested that stress should not be regarded as a defining factor of $\mathrm{CMT}$, taking into consideration the inconsistency of this factor in many studies ${ }^{16}$.

Concluding, the TCM must always be considered when sepsis or any systemic inflammatory response syndrome may course with clinical features of myocardial infarction. More studies in septic patients are associated with morbidity; the most common etiologies and mortality are necessary for that with this data as being possible to draw new guidelines and therapies which would reduce the morbimortality caused by the association between TCM and sepsis.

\section{ACKNOWLEDGEMENT}

We thank Dr. Paulo Borges Pinto and Neide Aragão Lima Dias Rocha for support in data collecting in Hospital de Messejana Dr. Carlos Alberto Studart Gomes. We also thank Dra. Rochelle Pinheiro Ribeiro for all the advices and for helping on the analysis of the obtained data.

\section{REFERENCES}

1. Lemos AET, Araújo ALJ, Lemos MT, Belém LS, Vasconcelos FJC Filho, Barros RB. Síndrome do coração partido (síndrome de Takotsubo). Arq Bras Cardiol.2008Jan; 90(1):e1-e3.

2. Pavin D, Le Breton $H$, Daubert C. Human stress cardiomyopathy mimicking acute myocardial syndrome. Heart. 1997Nov;78(5):509-511. PMC 189287.

3. Cramer MJM, De Boeck B, Melman PG, Sieswerda G. The 'broken heart' syndrome.Neth Heart J. 2007Sep;15(9):283-285.PMC 1995104.

4. Dhoble A, Abdelmoneim S, Bernier M, Oh JK, Mulvagh SL. Transient left ventricular apical ballooning and exercise induced hypertension during treadmil exercise testing: is there a common hypersympathetic mechanism?. Cardiovasc Ultrasound. 2008Jul 18;6:37.doi: 10.1186/1476-7120-6-37. PubMed PMID: 18638372.

5. Karvouniaris M, Papanikolaou J, Makris D, Zakynthinos E. Sepsis-associated takotsubo cardiomyopathy can be reversed with levosimendan. Am J Emerg Med. 2012 Jun;30(5):832.e5-7. doi: 10.1016/j.ajem.2011.02.030. PubMed PMID: 21530136

6. Geng S, Mullany D, Fraser JF. Takotsubo cardiomyopathy associated with sepsis due to Streptococcus pneumoniae pneumonia. Crit Care Resusc. 2008 Sep;10(3):231-4. PubMEd PMID: 18798722.

7. Bossone E, Erbel R. Takotsubo (Stress) Cardiomyopathy, An Issue of Heart Failure Clinics. 2.ed. Makati: Elsevier Health Sciences; 2013.

8. Sousa JMA, Knobel M, Buchelle G, Sousa JAM, Fisher CH, Born D, et al. Síndrome da disfunção apical reversível (Takotsubo). Arq Bras Cardiol. 2005; 84(4): 340-2. doi: http://dx.doi.org/10.1590/S0066-782X2005000400013.

9. Facciorusso A, Vigna C, Amico C, Lanna P, Troiano G, Stanislao M et al. Prevalence of Tako-Tsubo Syndrome among patients with suspicion of acute coronary syndrome referred to our centre. Int J Cardiol. 2009;134(2):255-259. doi: 10.1016/j.ijcard.2007.12.104. PubMed PMID: 18407362.

10. Kurisu S, Sato H, Kawagoe T, Ishihara M, Shimatani Y, Nishioka K, et al. TakoTsubo-like ventricular dysfunction with ST-segment elevation: a novel cardiac syndrome mimicking acute myocardial infarction. Am Heart J. 2002Mar;143:44855.PubMed PMID: 11868050.

11.Bybee KA, Kara T, Prasad A, Lerman A, Barsness GW, Wright RS, et al. Systematic review: transient left ventricular apical ballooning: a syndrome that mimics ST-segment elevation myocardial infarction. Ann Intern Med 2004 Dec; 141(11):858-865. PubMed PMID: 15583228.

12.Prasad A, Lerman A, Rihal CS. Apical ballooning syndrome (Tako-Tsubo or stress cardiomyopathy): a mimic of acute myocardial infarction. Am Heart J 2008Mar; 155(3):408-417. doi: 10.1016/j.ahj.2007.11.008. PubMed PMID: 18294473.

13. S. Ohigashi-Suzuki, Y. Saito, I. Tatsuno. Takotsubo cardiomyopathy associated with sepsis in type 2 diabetes mellitus. Am J Emerg Med. 2007 Feb; 25(2):230232. PubMed PMID: 17276831.

14. Palacio C, Nugent K, Alalawi R, Cevik C. Severe reversible myocardial depression in a patient with Pseudomonas aeruginosa sepsis suggesting tako-tsubo cardiomyopathy. Int J Cardiol. 2009 Jun 12; 135(1):e16-e19. doi: 10.1016/j.ijcard.2008.03.032. PubMed PMID: 18599133.

15. B. Kwiatkowska-PatzerB, PatzerJA, Heller LJ. Pseudomonas aeruginosa exotoxin $A$ enhances automaticity and potentiates hypoxic depression of isolated rat hearts. Proc SocExpBiol Med. 1993 Mar; 202(3): 377-383. PubMed PMID: 8437995.

16. Regnante RA, Zuzek RW, Weinsier SB, Latif SR, Linsky RA, Ahmed HN, et al. Clinical characteristics and four-year outcomes of patients in the Rhode Island Takotsubo Cardiomyopathy Registry. Am J Cardiol. 2009 Apr; 103(7): 10151019. doi: 10.1016/j.amjcard.2008.12.020. PubMed PMID: 19327433. 